GLOSSARY

\title{
Glossary of the World Trade Organisation and public health: part 1
}

\author{
Ronald Labonte, Matthew Sanger
}

J Epidemiol Community Health 2006;60:655-661. doi: 10.1136/jech.2005.037895

$\mathrm{T}$ he relation between health and trade is not new. Disease and pestilence have long followed global trade routes, a pattern that continues into the 21 st century. A Chinese trade ship was the source of Latin America's cholera outbreak in 1991, which resulted in 10000 deaths. ${ }^{1}$ Increased trade in tobacco products and processed foods high in sugar or fat contribute to rising chronic disease rates in poorer countries. $^{23}$

Trade can also be good for health, improving peoples' lives through access to goods or technologies that cure disease or improve wellbeing. Proponents of trade liberalisation argue further that it can increase economic growth and wealth creation, both of which may reduce poverty ${ }^{4}$ and allow for greater investments in health care, education, environmental protection, and other population health determinants. ${ }^{5}$ Others maintain that the relation is subtler. Development economist, Ha-Joon Chang ${ }^{6}$ points out that today's wealthy countries became so through a variety of policies-infant industry protection, export subsidisation, copying of foreign technologies, and strong state controls over foreign investment-that new trade liberalisation rules increasingly deny poorer countries.

Many of these trade rules came into existence with the creation of the World Trade Organisation (WTO) in 1995. The WTO's influence extends beyond commercial relations to affect health, social welfare, and culture. This two part glossary introduces the WTO trade treaties (the generic term for specific trade agreements) and explains the key principles and concepts of interest to policy makers and practitioners. It aims to explain the WTO through a public health lens that focuses on disease control and prevention, the reduction of a wide range of health risks, and a commitment to reducing health inequities. The public health implications of these agreements can be direct, as in the restrictions the Agreement on TradeRelated Intellectual Property Rights* (TRIPS) can place on access to essential medicines. They can also be indirect in two important ways:

(1) the degree to which WTO agreements skew economic benefits and the health advantages these bring in favour of already wealthier/ healthier nations and population groups; and

(2) WTO expansion into trade related areas that have little to do with reducing borderbarriers to imported goods, and that could restrict national governments' abilities to regulate in the interests of public health.
Part 1 of this glossary introduces the WTO and its origins as an institution, and summarises the WTO rules on trade in goods that are most relevant to public health. Part 2 considers rules specific to trade in services, intellectual property, investment, and government procurement. $\dagger$

\section{THE WORLD TRADE ORGANISATION}

Creation of the WTO in 1995 capped a set of negotiations known as the Uruguay Round after the country in which meetings began. The Uruguay Round, which began in 1986, extended trade treaties beyond goods to include services, intellectual property rights, and investment measures. All but two of these treaties (on government procurement and on trade in civil aircraft) are multilateral trade agreements to which all nations must accede as a condition of WTO membership.

Under the WTO, trade rules - the obligations laid out within trade agreements that are binding on member countries-also became enforceable. The WTO's predecessor, the General Agreement on Tariffs and Trade (GATT), founded in 1947, relied on commercial diplomacy to settle differences between members. The WTO established a legal dispute settlement process that is ultimately enforceable by allowing aggrieved members to take retaliatory trade actions against the offending member country. This process makes the WTO one of the key institutions of global economic governance. Functioning as a forum for multilateral trade negotiations, the WTO has an influence far beyond what might be suggested by the size of its Secretariat, which is small relative to other multilateral institutions. Its membership has grown to 148 nations, and all but a very few of the remaining nations of the world are engaged in efforts to accede to the WTO. Ongoing negotiations at the WTO aim to extend further the reach of its trade rules, through creation of new agreements and by extending the coverage of existing ones.

The preamble of the Marrakech Agreement, the WTO's founding document, states that trade liberalisation is not an end in itself but a means "to raising standards of living, ensuring full employment and a large and steadily growing volume of real income and effective demand, and expanding the production of and trade in goods

*Italicised terms refer to glossary entries or other key terms defined within a particular glossary entry.

${ }^{\dagger}$ A general glossary on trade terms, without specific reference to health, can be found on the web site of the World Trade Organisation; http://www.wto.org/ english/thewto_e/glossary_e/glossary_e.htm. 
Table 1 WTO agreements with major public health implications

\begin{tabular}{|c|c|}
\hline Agreement & Health impacts \\
\hline GATT 1994 & $\begin{array}{l}\text { Reduced tariffs in many developing countries led to job losses in "uncompetitive" sectors, with subsequent } \\
\text { impacts on poverty, and declines in net public revenue, decreasing the funds available for health, education, } \\
\text { water/sanitation, and other key health determinants. }\end{array}$ \\
\hline Agreement on Agriculture & $\begin{array}{l}\text { Continuing export and producer subsidies by the USA, EU, Japan and Canada depress world prices and cost } \\
\text { developing countries hundreds of millions of dollars in lost revenue that could be used to fund health, education, } \\
\text { and other health promoting services. Subsidised food imports from wealthy countries undermine domestic } \\
\text { growers' livelihoods. Market barriers to food products from developing countries persist and deny poorer } \\
\text { countries trade related earnings. }\end{array}$ \\
\hline $\begin{array}{l}\text { Agreement on Sanitary and Phytosanitary } \\
\text { Measures }\end{array}$ & $\begin{array}{l}\text { Requires scientific risk assessments even when foreign goods are treated no differently than domestic goods } \\
\text { (that is, there is no discrimination). Such assessments may be costly and imperfect. }\end{array}$ \\
\hline Technical Barriers to Trade Agreement & $\begin{array}{l}\text { Requires that any regulatory barrier to the free flow of goods be "least trade restrictive as possible." Many } \\
\text { trade disputes over domestic health and safety regulations have invoked this agreement. }\end{array}$ \\
\hline General Agreement on Trade in Services & $\begin{array}{l}\text { Locks in privatisation levels in committed service sectors, several of which (health care, education, } \\
\text { environmental services) are important to promoting public health, and frequently prone to market failure (that } \\
\text { is, private provision often excludes access to the poor). Once a service sector is committed, there is no cost-free } \\
\text { way to extend public provision of that service in the future. }\end{array}$ \\
\hline $\begin{array}{l}\text { Agreement on Trade Related Intellectual } \\
\text { Property Rights }\end{array}$ & $\begin{array}{l}\text { Extended patent protection can limit access to essential medicines. Higher resulting cost of drugs can consume } \\
\text { public funding otherwise useful for primary health care or investing in other health determinants. }\end{array}$ \\
\hline $\begin{array}{l}\text { Agreement on Trade Related Investment } \\
\text { Measures }\end{array}$ & $\begin{array}{l}\text { Prohibits government's abilities to place domestic purchase requirements on foreign investment; such } \\
\text { requirements can increase domestic employment, which can be important to improving population health. }\end{array}$ \\
\hline Agreement on Government Procurement & $\begin{array}{l}\text { Limits government's abilities to use its contracts or purchases for domestic economic development, regional } \\
\text { equity, employment equity or other social goals with strong links to better population health. While currently a } \\
\text { plurilateral (voluntary) agreement, there is negotiating pressure to make it a binding multilateral agreement. }\end{array}$ \\
\hline
\end{tabular}

and services...in accordance with the objective of sustainable development". ${ }^{7}$ In practice, as the WTO Secretariat states, "the system's overriding purpose is to help trade flow as freely as possible" ${ }^{8}$ Unlike trade rules, preambles to agreements are not enforceable. The key concern with enforceable trade rules is the extent to which liberalisation becomes the end in itself, to which health and human development goals are rendered secondary considerations.

\section{KEY "TRADE TALK" TERMS}

\section{Measures}

Trade rules apply only to government actions. In trade treaties these actions are called measures, a term that includes legislation, regulations, rules, procedures, decisions, and administrative actions. WTO rules for government measures span the entire field of public health, including inter alia:

- surveillance and control of infectious disease

- regulation of hazardous products

- control of environmental health risks

- provision of food security and nutrition

- regulation of the health risks of biotechnology and emerging technologies

- provision of access to health services and essential medicines

- measures to prevent chronic disease.

\section{Tariffs}

Trade rules under the original GATT applied exclusively to tariffs, which are customs duties on imported goods generally used to protect domestic producers from foreign competition. Successive rounds of negotiations have reduced tariff levels of high income countries on industrial goods to around $4 \%$, although tariffs on agricultural products of greater economic interest to developing countries remain much higher.'
Developing countries retain tariffs of $40 \%$ or more to protect their developing industries, although they are under strong pressure to commit to freezing tariff rates and begin to reduce them.

\section{Non-tariff barriers}

The GATT $1994 \ddagger$ and other WTO agreements were extended to apply to a broader range of measures that may restrict trade. These include measures that have public health objectives as their primary purpose and may only incidentally restrict access of goods or services into a country, or impinge on the operations of foreign investors. Measures identified as non-tariff barriers in recent health related WTO trade disputes include regulation of advertising for tobacco products, standards to limit gasoline emissions, and a ban on artificial growth hormones in beef. By defining such measures as trade barriers, the concept of non-tariff barriers has helped to make modern trade treaties far more intrusive than their predecessors.

\section{Trade liberalisation}

This is the process of reducing tariff levels and of making other government measures less trade restrictive. Classic economists view increased trade as beneficial to all participants because it generates higher levels of income and consequently better health. Who benefits from multilateral trade liberalisation, however, is determined significantly by the institutions and rules that govern WTO negotiations. Through procedural rules, informal alliances, and the ability to afford a large number of negotiators at the WTO, the most powerful countries have dominated WTO trade negotiations. ${ }^{10}$ Many observers believe that multinational corporations and their shareholders have been the main beneficiaries of the resulting form of trade liberalisation. Alliances of

₹The GATT refers to both a trade treaty (revised in 1994) and the institution that served as a forum for multilateral trade negotiations before the creation of the WTO. 
smaller and developing countries and civil society organisations are increasingly demanding that other interests be better represented at the WTO.

\section{Trade treaty commitments}

Reduction of tariffs and liberalisation of other measures affecting trade is achieved either through commitments made in trade negotiations or unilaterally by national governments. WTO negotiations take place within the framework of its different specific agreements, with the intent of "progressive liberalisation" through ongoing reduction in tariff and non-tariff barriers to trade. These negotiations are increasingly multilateral, in which all members attempt to agree on a formula for reducing such barriers. They can also proceed on a request-offer basis, in which each member country identifies the measures of other countries it seeks to change, and then responds to the requests of other countries by offering commitments to liberalise measures that other countries have identified. These bilateral negotiations result in liberalised trade for all WTO members because commitments made in the request-offer process are subject to the most-favoured nation rule that stipulates that any advantage provided to one WTO member must be provided to all (see below).

\section{Trade negotiations}

Multilateral trade negotiations entail concurrent talks on several agreements. While consensus is more easily reached on some issues than others, no negotiating round is concluded until there is consensus on all agreements. Described as a "single undertaking", this approach is an "all or nothing" rule, an innovation of the Uruguay Round that requires consensus on all of the agreements under negotiation. The Tokyo Round of GATT negotiations (197379) was the first to introduce a number of sub-agreements on non-tariff measures, but member countries could pick and choose which of these they would sign and implement. Wealthier countries believed this gave too much benefit to developing nations, few of which signed these sub-agreements. Many analysts now believe the Uruguay Round's single undertaking, in which these voluntary sub-agreements became obligatory WTO treaties, tipped trade agreements too strongly in favour of developed nations. ${ }^{11}$ Each negotiating round is concluded at a Ministerial Conference at which the international trade ministers of each member nation preside. The most intractable issues are referred to the trade ministers, and may be negotiated under intense pressure in a Ministerial Conference as they near a negotiating deadline.

The Uruguay Round negotiations were the eighth round of multilateral trade negotiations since the creation of GATT. An effort to start a ninth, the Millennium Round, failed at a 1999 Ministerial Conference in Seattle, USA, over differences between wealthy and developing nations and under intense pressure from critics of trade liberalisation. A subsequent Ministerial Conference in Doha, Qatar in 2001, a location chosen to guard against protests, succeeded in launching a new set of negotiations, dubbed the Doha Development Round.

\section{Doha development round}

Key agenda items of the Doha Ministerial Conference included:

(1) Developing countries' insistence that the next round of negotiations be a development round focused primarily on issues like improving access to markets in the industrialised world;

(2) Developed countries' (unsuccessful) insistence to include the Singapore Issues in the new round of negotiations (named for the earlier Ministerial Conference in Singapore where they were first discussed, these refer to proposed agreements on competition, investment, transparency in government procurement, and trade facilitation);

(3) Controversy about the conflict between TRIPs and efforts in low income countries to provide access to essential medicines.

Two important official documents released at the conference's conclusion, the Doha Ministerial Declaration and the Declaration on TRIPS and Public Health, ${ }^{12}{ }^{13}$ showed an intention to place developing countries' interests "at the heart" of the WTO work programme. Some observers, however, argue that the actual Doha work programme was "totally set by the major developed countries guided by their own economic interests". ${ }^{14}$ In any case, developing countries, led by an informal coalition of low and middle income nations and frustrated by the intransigence of high income countries in areas of interest to them (agricultural subsidies, special and differential treatment and implementation issues, defined below), forced the early termination of the next ministerial in Cancún, Mexico, in September 2003. After a period of disarray, a deal to restart negotiations was brokered by five key members (Australia, Brazil, the EU, India, and the USA) and a revised deadline of the end of 2006 was set for completing negotiations, although many contentious issues remain.

\section{CORE PRINCIPLES OF WTO TREATIES Most favoured nation (MFN) and national treatment (NT) rules}

Non-discrimination on the basis of nationality is the golden rule of the international trading system. Trade treaties include two distinct rules that apply the principle of nondiscrimination to government measures.

The most favoured nation (MFN) rule requires that governments extend the best treatment given to any foreign goods, investments, or services to all like foreign goods, investments, or services. In simple terms, a government must provide equal treatment to similar goods imported from any WTO member nation, apart from exceptions permitted under the Generalised System of Preferences (defined under Exceptions, Limitations and Exclusions, below). The implications of the MFN are more far reaching and complex when applied to services. For instance, a provider of diagnostic services over the internet could be entitled to the same level of treatment as similar services provided by a foreign owned laboratory actually operating in the country.

The national treatment rule requires that governments give foreigners the best treatment provided to like domestic goods, investments, or services. Governments cannot discriminate against foreign investors or businesses on the basis of their nationality. International trade law has established a high standard of non-discrimination. Measures that are not explicitly discriminatory may yet violate the MFN and national treatment rules if they adversely affect the "equality of competitive opportunities" of foreign investors or businesses. Since the mid-1990s the principle of non-discrimination has been extended beyond trade in goods to apply to investment and trade in services, raising new concerns for regulating health care systems.

\section{Dispute settlement}

The Dispute Settlement Understanding (DSU)§ is probably the most significant innovation of the WTO. Trade disputes under the WTO are overseen by a standing Dispute Settlement

${ }^{\S}$ Its proper title is: "Understanding on Rules and Procedures Governing the Settlement of Disputes;" but it is most commonly referred to as the Dispute Settlement Understanding or DSU. 
Body (DSB) that has the power to establish panels to resolve conflicts, monitor adherence to dispute decisions, and implement penalties for non-compliance. If initial consultations cannot resolve a dispute, the matter is referred to a three member panel that, like a judicial body, hears submissions from the parties in dispute (and in some cases third parties) and issues a binding report. A panel report can be appealed, within a limited period, to the standing Appellate Body $(A B)$ that can uphold, modify, or overturn a decision. The $\mathrm{AB}$ is composed of seven trade and legal experts appointed for four year terms. This institutional framework provides for a degree of consistency that was absent before the WTO, and has begun to generate a body of jurisprudence on the settlement of international trade disputes. DSB rulings, however, do not set binding precedents for future disputes. ${ }^{15}$

Proceedings of the dispute panels and appellate body are confidential. Only other WTO members with a material interest in a conflict can apply to make submission as a third party. There is no provision for interventions by public interest bodies or other NGOs. While these procedures are consistent with those for the settlement of private commercial disputes, their application to far reaching WTO trade rules means that disputes with important public interest implications are shrouded in secrecy.

If a government measure is found in violation of a trade obligation, it is required to repeal or modify the offending measure. Trade retaliation is the ultimate sanction against a government that refuses to change a measure found to be in violation of its WTO trade commitments. The WTO permits the complainant governments to impose high tariffs or other trade sanctions against imports of the offending country. These sanctions, which do not have to affect the same kinds of goods involved in the trade dispute, are often designed to have maximum political impact.

\section{Exceptions, limitations, and exclusions}

Certain measures that are inconsistent with WTO rules can be maintained if the government responsible shows that they meet the terms of an exception, limitation, or exclusion in a WTO treaty.

Exceptions are conditions that apply to all countries. The GATT 1994 and GATS include very similar exceptions concerning measures "necessary to protect human, animal or plant life and health" (GATT article XX(b), GATS $\mathrm{XIV}(\mathrm{b})) \cdot \uparrow$ While these exceptions are often claimed adequate to protect public health measures, their effect has been limited to date. Dispute panels apply a stringent necessity test that assesses the various measures available to achieve a public health objective. It further requires that the government in question use only the measure least burdensome to trade. In almost 50 years of GATT and 10 years of WTO disputes, only one dispute panel (on Canada's attempts to overturn a French ban on asbestos imports) has upheld an otherwise inconsistent measure on the basis of this exception. **

Another exception is provided by the Generalised System of Preferences (GSP), "a relaxation of the MFN [most favoured nation] clause"16 that allows wealthy countries to offer preferential tariffs to low income nations of their choosing.

"The GATS, or General Agreement on Trade in Services, is a complex treaty covering liberalisation of trade in services. Detail on GATS is provided in part 2 of this glossary.

"** The panel found that the French ban did discriminate against Canadian asbestos, as it was "like" the glass fibres used for French insulation. The Appellate Body, however, considered the huge body of evidence of health risks associated with asbestos sufficient to justify the ban.
This exception allows the European Union's "Everything but Arms" initiative that eliminates tariffs on all imports from least developed countries except weapons; and the USA's African Growth and Opportunities Act (AGOA) that gives preference to imports from African countries that meet certain conditions. The GSP can improve health if the preferential treatment given to eligible countries leads to poverty reduction through wealth creation. But the GSP has also been criticised for excluding items of particular importance to poor countries; favouring raw goods over manufactured products; linking preferences to other conditions such as intellectual property rights or, in Latin America, the "war on drugs"; and being used as leverage in WTO negotiations to gain developing country acceptance of positions favoured by, and favouring, wealthy member nations. ${ }^{17}{ }^{18}$

Limitations (or specific exceptions) refer to conditions stipulated by individual countries concerning their commitments in a trade treaty. These conditions qualify how the trade rules concerning specific goods or services apply to measures of that country only. WTO negotiations aim to limit and eventually eliminate all such country specific limitations.

Exclusions are measures, goods, or services that are entirely outside the scope of a WTO trade agreement. The GATS "governmental authority" exclusion, for example, provides some protection for certain public health and other measures, but its significance is subject to interpretation and has not been tested in a dispute. (Detail on GATS is provided in part 2 of this glossary.)

\section{Special and differential treatment}

While not an exception in a strict sense, special and differential treatment (SDT) has been a feature of the world trading system since the beginning of the GATT. SDT affords a lower level of obligation to trade agreements for developing nations. With the birth of the WTO, SDT suffered a "massive dilution". ${ }^{19}$ Rather than SDT meaning a lower degree of obligation, it now means only a longer time frame to adjust to, and fulfil, all obligations of most agreements. This may be good for global economic growth, but is unlikely to benefit global equity; as the recent World Commission on the Social Dimensions of Globalisation noted, "Uniform rules for unequal partners can only produce unequal outcomes". ${ }^{20}$

Many SDT provisions are written in "best endeavour" language that "calls on," but does not require, members to take the development needs of poorer countries into account..$^{21}{ }^{22}$ Intense developing country lobbying led to inclusion in the Doha Ministerial Declaration ${ }^{23}$ of a commitment to review "all Special and Differential provisions...with a view to strengthening them and making them more precise, effective and operational". WTO members, however, disagree over what "strengthening" means. Developing countries want to modify many agreements to make them more supportive of health and development objectives, partly by granting them more policy flexibility. ${ }^{11}$ Most developed countries oppose this. ${ }^{24}$ Even though the Doha Ministerial mandated members to identify "best endeavour" SDT measures and "to consider the legal and practical implications ... of converting them into mandatory provisions", ${ }^{\prime 25}$ no progress was made by the July 2002 deadline, and little progress since. ${ }^{9}$

From a public health vantage, trade treaties should revert to the pre-WTO principle of non-reciprocity (in which negotiations do not assume equality in liberalisation commitments from developing countries); and health and development goals should be a screen before a trade challenge entailing a developing country goes to a dispute panel (that is, trade obligations could be violated if the clear intent is to achieve such goals). 


\section{PUBLIC HEALTH IMPLICATIONS OF AGREEMENTS COVERING TRADE IN GOODS GATT 1994††}

The GATT 1994 is the overarching treaty on trade in goods and includes all WTO members' commitments to further reduce tariffs on imported goods. This can yield health benefits if it results in cheaper prices for food, clothing, and other health essentials, or reduces the prevalence of poverty by lowering their preliberalisation prices. But these benefits so far have been globally asymmetrical, with greater gains in developed nations because of their greater purchasing power. They are also often nationally asymmetrical, with job losses in the manufacturing sectors of developed countries, as production moves to Latin America, Asia, and especially China; and increased rural/urban inequalities in developing countries, as export led industrialisation creates growth related wealth for a minority in the urban centres. ${ }^{26}$ Together with liberalisation in capital markets, which makes foreign investment easier, tariff reduction has led to the growth of "global production chains". These chains allow multinational enterprises to locate labour intensive operations in low wage countries (often in exclusive export processing zones), carry out research and development in countries with high levels of publicly funded education and investment in research, and declare most of their profits in low tax countries. The result is global tax competition and lower corporate tax revenues in all countries. ${ }^{27}{ }^{28}$

Tariff reductions can also have powerful indirect health impacts, particularly for developing countries, including:

- Reduced funding for public health services: tariffs have been an important source of public revenue in poorer countries, which have less domestic wealth and income that can be taxed. Few developing countries have been able to replace revenues lost from tariff reduction with other forms of taxation. ${ }^{35}$ Consequently, less public funding is available for health care, education, water and sanitation, and gender empowerment programmes; or for enforcement of occupational, environmental, or labour rights and standards.

- Unemployment and precarious employment: tariffs are a more significant form of industrial support for poorer countries, which are less capable than wealthy countries to subsidise their domestic industries. Reduced tariff levels have forced the closure of some companies that are no longer able to compete against more technologically advanced or more highly subsidised competitors. This can lead to increased unemployment and precarious employment (both with negative health effects) and further reductions in government revenue.

\section{Agreement on agriculture}

All countries provide support to their domestic farming sectors in the form of subsidies, quotas, price supports, import controls, or other means. These measures have various public policy objectives, sometimes referred to as multifunctionality, such as securing a stable domestic food supply, ensuring that marginalised groups or regions have equitable access to nutrition, or maintaining distinctive rural cultures and ways of life. A consequence of these measures may also include restricting agricultural imports.

Trade in agricultural goods was excluded from multilateral trading rules before the WTO. This changed with the Agreement on Agriculture (AoA), which was negotiated during the Uruguay Round primarily as a means to resolve

${ }^{t+}$ The full legal text of this, and all other WTO agreements, can be found on the WTO web site: http://wto.org.
Trade liberalisation, poverty, inequalities, and health

It is hard to generalise the relation (positive or negative) between trade liberalisation, poverty, and health. Much depends on pre-existing conditions in particular countries. Goods produced in countries with weaker economies, poorer infrastructures, less educated and unhealthier people, and little technological advancement generally cannot compete with the goods produced in countries where the opposite conditions prevail. This has been particularly the case with many African countries. Other developing nations have fared better. Economic growth and poverty reduction in China and India are the commonly cited examples. There is fierce debate, however, over how extensive this poverty reduction has been, ${ }^{29}{ }^{30}$ although there is little disagreement that inequalities have risen sharply in both nations. Moreover, import liberalisation in both countries only began after both countries experienced significant export led growth. Labour conditions in China's export processing zones, the "engines' of this growth, have been routinely cited as arduous, unsafe, and unhealthy. ${ }^{3}$

Most high income nations, in turn, have experienced significant changes in their labour markets, and not just in their manufacturing sectors. "Precarious employment", characterised by shorter working hours, fewer benefits and lack of union protection, has grown in many, though not all, countries. ${ }^{32} 33$ Even high technology jobs are moving from high wage high income countries to low wage middle income countries that have a growing educated workforce.

The broadly stated facts are these: The post-second world war period (1950-1980) witnessed high rates of global economic growth, the development of welfare systems in most high income nations and the independence of former colonies. Income and health inequalities within and between nations declined during this period. Subsequent to the rise in neoliberal economic policies, including liberalisation in trade and financial markets, health and income inequalities within and between nations began to rise (with the exception of Western Europe), and sharply so since the early 1990 s. ${ }^{34}$ To some observers, these inequalities are the short term pain that must be paid for the longer term benefits promised by a fully integrated global market. To others, they show a critical failure in national and global policies that need immediate rectification.

the trade war between the USA and EU over international food and agricultural markets. It commits WTO members to reduce tariffs and to phase out subsidies to farmers and to food exporters. The agreement gave WTO members a 10 year implementation period (which ended 31 December 2004) during which agricultural supports were exempt from trade actions under the GATT 1994 rules on subsidies, tariffs, and dumping.㧊

How the AoA affects public health depends not only on the wealth of a country and whether it is a net food importer or exporter, but also on the significance of agricultural trade and domestic policies for specific populations. Developing country

\# "Dumping" refers to exports that enter markets at less than "normal" prices. Another WTO agreement covers this practice, allowing members to impose countervailing measures, such as tariffs, if they believe dumping is occurring. This provision has often been used by wealthier countries to reduce imports of goods from developing countries where labour costs are substantially cheaper. Dispute panels eventually and generally rule in favour of developing countries, but not before substantial damage is done to their export industries. 
negotiators charge that continuing USA, EU, and Japanese agricultural import tariffs and production subsidies hinder trade related growth and poverty reduction in developing countries. Estimates of these annual losses for developing countries range between US $\$ 20$ and $\$ 60$ billion. ${ }^{36}$ A July 2004 WTO "framework agreement" to begin phasing out subsidies may remedy this impasse, but details are still subject to negotiation and the USA has stated it will not begin to negotiate such reductions until after developing countries lower their agricultural tariffs. ${ }^{37}$ The August 2004 agreement also allows the USA to retain a US\$180 billion increase in domestic farm subsidies announced in 2002, as long as it can show that they do not affect current levels of agricultural production.§§ In the lead up to the expiry of the AoA 10 year implementation period, Brazil successfully challenged USA cotton and EU sugar subsidies under the AoA ${ }^{38}$; a flurry of further challenges to agricultural subsidies is expected. Intense negotiations over agriculture at the 2005 Hong Kong ministerial meeting led to agreement on a 2013 date for phasing out all export subsidies. Developed country export subsidies for cotton will be eliminated in 2006. Difficult issues related to domestic supports for agriculture, including cotton and sugar, have yet to be resolved.

While gaining market access for agricultural exports would be of some economic benefit to exporting countries, trade liberalisation in food products may hurt public health through additional environmental stresses, notably in already water scarce regions in Africa ${ }^{39}$ and decreased food security as production is skewed to export products rather than domestic needs. ${ }^{4041}$ It can also increase women's labour time in household food production ${ }^{42}$ and benefit primarily men who dominate the agricultural export sector in most developing countries. The agricultural supports targeted for removal by the AoA also benefit public health for certain groups. Many poor food importing countries benefit by lower world prices caused by subsidies. Many rich countries use quotas or other means to regulate supply of certain agricultural products to promote domestic food security, and to support regional development and rural economies. These measures are vulnerable to challenge under the AoA.

Resolving these dilemmas requires, at a minimum, substantial special and differential treatment (SDT) for developing countries, where agriculture is closely tied to livelihood and sustenance. ${ }^{16}$ Developing countries are still permitted some exemptions under the AoA, but these are limited and current negotiations bind all WTO members to begin reducing agricultural tariffs. Developing countries argue for a "development box" that would allow them to retain or reinstate tariffs for rural development, food security, and poverty alleviation purposes, ${ }^{43}$ a premise readily defensible on public health grounds.

\section{Agreement on the application of sanitary and phytosanitary measures (SPS)}

The SPS agreement sets out rules for public health measures to ensure food safety and to control plant or animal carried diseases. It is not a health agreement; rather it limits health regulations that may affect trade in agricultural goods. Examples of measures that could be affected by the SPS include limits on pesticide residues in food, inspection of products for contaminants, requirements for decontamination treatments, and bans on animals or animal products from areas in which a disease outbreak has occurred. The SPS defines the conditions under which these public health

\footnotetext{
${ }^{\S \S}$ As many commentators pointed out, the 2002 US subsidy programme also ran counter to its commitment made in Doha in November 2001 to "reductions, with a view to phasing out, all forms of [agricultural] export subsidies; and substantial reductions in trade-distorting domestic support" [our emphasis]. ${ }^{12}$
}

measures can restrict trade without violating trade rules. They are more stringent than the GATT rules, requiring additional conditions that even non-discriminatory measures must meet.

Proponents argue that the SPS does not limit a government's ability to enact public health measures, but only requires that they conform to defensible, scientific criteria to ensure that they are not a disguised restriction on trade. WTO dispute panels, however, have interpreted and applied these rules to the benefit of exporters, effectively determining the scientific merits of competing studies without necessarily the scientific expertise to evaluate the evidence. All three SPS cases decided at the WTO to date have gone against the government that used the health measure.

The best known SPS case was an EU ban on foreign beef that contains artificial growth hormones banned in the Europe because they may be carcinogenic. The dispute panel ruled against the EC ban partly because international standards had been set for five of the six hormones in question. ${ }^{44}$ The SPS (III.1) prefers government regulations to be based on international standards, specifically those of the Codex Alimentarius Commission (Codex). The Codex is a joint FAO/WHO Food Standards Programme. That the dispute panel ignored is that the Codex adopted a "safe" level of hormone use by a very narrow vote of 33 to 29 , with seven abstentions**; and that Codex itself has been criticised for having an overwhelming majority of corporate scientists with very limited participation by civil society organisations. Standards setting and risk assessments are not simply "scientific;" they are also political and contested, particularly in the case of uncertainty. The Appellate Body, while acknowledging that there could be a health risk, found against the EU because it had failed to conduct a proper risk assessment of the misuse of the beef hormones as required by the SPS. In 1999, the WTO sanctioned trade retaliation by the USA and Canada against the EU, which refused to lift the ban. In adhering narrowly to the requirement for a risk assessment, this decision placed the burden of proof on the EU to show that beef imports were unsafe, rather than on the USA and Canada to show that they were safe. The European Commission in November 2004 filed its own complaint against the continuing trade sanctions, arguing that its growth hormone legislation is now based on a full scientific risk assessment and no longer violates the SPS agreement. ${ }^{45}$

\section{PART 2 OF GLOSSARY}

This concludes part 1 of our glossary. Part 2 will focus on agreements covering services, intellectual property rights, investment and government procurement, and conclude with a commentary on the public health implications of the explosive growth of bilateral and regional liberalisation agreements.

\section{ACKNOWLEDGEMENTS}

For helpful comments and contributions to an earlier draft, Ted Schrecker, senior policy researcher, Globalization and Health Equity, Institute of Population Health University of Ottawa; and Scott Sinclair, Trade Policy Analyst, Canadian Centre for Policy Alternatives; and to three reviewers.

"The use of international standards can have mixed public health implications. On the one hand, it can limit national sovereignty in setting standards higher than those that might be scientifically defensible at any given time. On the other, it can impose a higher level of safety than that presently found in many developing countries that lack the resources to attain such standards. This restricts their export earning capacity, with its potential poverty reducing effects.

${ }^{* * *}$ While the Codex uses technical committees to develop standards, only governments have formal voting power. 


\section{Authors' affiliations}

R Labonte, Globalization and Health Equity, Institute of Population Health, University of Ottawa, Ontario, Canada

M Sanger, Canadian Centre for Policy Alternatives, Ottawa, Ontario, Canada

\section{REFERENCES}

1 Kickbusch I, Buse K. Global influences and global responses: International health at the turn of the 21 st century. In: Merson MH, Black RE, Mills AJ, eds. Handbook of international public health. New York City: Aspen, 2001:701-37

2 Lee K. Globalization: a new agenda for health? In: McKee M, Garner P, Scott R, eds. International co-operation in health. Oxford: Oxford University Press, 2001:13-30.

3 Yach D, Beaglehole R. Globalization of risks for chronic diseases demands global solutions. Perspectives on Global Development and Technology 2004;3:213-34.

4 Dollar D. Is globalization good for your health? Bull World Health Organ 2001;79:827-33.

5 Dollar D, Kraay A. Growth is good for the poor. http://www.worldbank.org/ research (accessed 22 Jan 2002)

6 Chang HJ. Kicking away the ladder: development strategy in historical perspective. London: Anthem Press, 2002.

7 Jawara F, Kwa A. Behind the scenes at the WTO: the real world of international trade negotiations. London: Zed Books, 2003:9, 12.

8 World Trade Organisation. European communities-measures affecting asbestos and asbestos containing products: report of the panel. http:// www.worldtradelaw.net/reports/wtoab/ec-asbestos(ab).pdf.

9 Khor M. Global Trends. http://www.twnside.org.sg/title2/gtrends47.htm (accessed 9 May 2005).

10 Jawara F, Kwa A. Behind the scenes at the WTO: the real world of international trade negotiations. London: Zed Books, 2003.

11 Keck A, Low P. Special and differential treatment in the WTO: why, when and how? Geneva: World Trade Organisation, 2004.

12 World Trade Organisation. Ministerial Declaration WT/MIN(01)/DEC/1. $\mathrm{http}$ ///www.wto.int/english/thewto_e/minist_e/min01_e/mindecl_e.htm.

13 World Trade Organisation. Declaration on the TRIPs agreement and public health WT/MIN(01)/DEC/2. http://www.wto.org/english/thewto_e/ minist_e/min01_e/mindecl_trips_e.htm.

14 Das BL. In:, Jawara F, Kwa A. Behind the scenes at the WTO: the real world of international trade negotiations. London: Zed Books, 2003, 119.

15 Garcia FJ. Beyond special and differential treatment. Boston College Int Comp Law Rev 2004;27:291-317.

16 Das BL. The world trade organisation: a guide to the framework for international trade. New York: Zed Books, 2000

17 World Trade Organisation. The generalised system of preferences: a preliminary analysis of the GSP Schemes in the quad, WT/COMTD/W/93.

18 Jawara F, Kwa A. Behind the scenes at the WTO: the real world of international trade negotiations. London: Zed Books, 2003:152-5.

19 Das BL. The world trade organisation: a guide to the framework for international trade negotiations. New York: Zed Books, 2000:8.

20 World Commission on the Social Dimension of Globalization. A fair globalization: creating opportunities for all. Geneva: International Labor Organisation, 2004, http://www.ilo.org/public/english/wcsdg/docs/ report.pdf.

21 Jawara F, Kwa A. Behind the scenes at the WTO: the real world of international trade negotiations. London: Zed Books, 2003, 12, 47.

22 Garcia FJ. Beyond special and differential treatment. Boston College Int Comp Law Rev 2004;27:291-317.
23 World Trade Organisation. Ministerial Declaration WT/MIN(01)/DEC/1. http://www.wto.int/english/thewto_e/minist_e/min01_e/minded_e.htm.

24 BRIDGES Weekly Trade News Digest 2002;6:08. http://www.ictsd.org/ weekly/ (accessed 5 Jul 2005).

25 World Trade Organisation. Doha Decision on implementation-related issues and concerns. WT/MIN(01)/17. Para. 12(i).

26 United Nations Human Settlements Programme (UN-HABITAT). Slums of the world: the face of urban poverty in the new millennium? Nairobi: UN Habitat, 2003, http://www.unhabitat.org/publication/slumreport.pdf /accessed 1 Feb 2005).

27 Grunberg I. Double jeopardy: globalization, liberalization and the fiscal squeeze. World Dev 1998;26:591-605.

28 Wade RH. Bridging the digital divide: new route to development or new form of dependency. Global Gov 2002a;8:443-66

29 Wade RH. Globalisation, poverty and income distribution: does the liberal argument hold? In: Gruen D, O'Brien T, Lawson J, eds. Globalisation, living standards and inequality: recent progress and continuing challenges, proceedings of a conference held in Sydney, 27-28 May 2002. Canberra: Reserve Bank of Australia, 2002, 37-65. http://www.rba.gov.au/ PublicationsAndResearch/Conferences/2002/.

30 Deaton A. Measuring poverty in a growing world (or measuring growth in a poor world. Rev Econ Stat 2005; 1:1-19.

31 ICFTU (International Confederation of Free Trade Unions). Export processing zones - symbols of exploitation and a development dead-end. Brussels: ICFTU, 2003, http://www.icftu.org/www/pdf/wtoepzreport2003-en.pdf.

32 Fligstein N, Shin TJ. The shareholder value society: a review of the changes in working conditions and inequality in the US, 1976-2000. Berkeley: University of California Berkeley Institute of Industrial Relations, 2003, http:// repositories.cdlib.org/cgi/viewcontent.cgi?article =1026\&context = iir.

33 Polanyi M, Tompa E, Foley, J. Labor market flexibility and worker insecurity. In: Raphael D, ed. Social determinants of health: Canadian perspectives. Toronto: Canadian Scholars' Press, 2004:67-77.

34 Cornia C, Menchini L. The pace and distribution of health improvements during the last 40 years: some preliminary results, 2005. http:// www.networkideas.org/featart/feb2005/Cornia_Menchini_Paris_Paper.pdf.

35 Hilary J. The wrong model: GATS, trade liberalisation and children's right to health. London: Save the Children, 2001.

36 World Bank. World development report 2000/2001: attacking poverty. Washington: World Bank, 2001

37 BRIDGES Weekly Trade News Digest 2004;8:24. http://www.ictsd.org/ weekly/ (accessed 5 Jul 2005).

38 BRIDGES Weekly Trade News Digest 2004;8:28. http://www.ictsd.org/ weekly/ (accessed 5 Jul 2005)

39 Labonte R, Schrecker T, Sanders D, et al. Fatal indifference: the G8, Africa and global health. Cape Town: University of Cape Town Press, 2004

40 Food and Agricultural Organisation. Rural women and food security: current situation and perspectives. Rome: Food and Agricultural Organisation, 1996.

$41 \mathrm{Karl}$ M. Higher agricultural education and opportunities in rural development for women. Rome: Food and Agricultural Organisation, 1997.

42 Tibaijuka, A. The cost of differential gender roles in Africa agriculture: a case study of smallholder banana-coffee farms in Kagera Region. Am J Agric Econ 1994;45:69-81.

43 Labonte R. Globalization trade health: unpacking the linkages, defining the healthy public policy options: In: Hofrichter R, ed. Health and social justice: politics, ideology and inequity in the distribution of disease. San Francisco: Jossey-Bass, 2003:469-500.

44 World Health Organisation/World Trade Organisation. WTO agreements and public health. Geneva: World Health Organisation/World Trade Organisation, 2002.

45 BRIDGES Weekly Trade News Digest 2004;8:10. http://www.ictsd.org/ weekly/ (accessed 5 Jul 2005) 
GLOSSARY

\title{
Glossary on the World Trade Organisation and public health: part 2
}

\author{
Ronald Labonte, Matthew Sanger
}

J Epidemiol Community Health 2006;60:738-744. doi: 10.1136/jech.2005.038950

Part 1 of this glossary introduced different health and trade arguments, overviewed the history of the World Trade Organisation (WTO), defined key "trade talk" terms, and reviewed three WTO treaties concerned with trade in goods (GATT 1994, the Agreement on Agriculture, and the Agreement on Sanitary and Phytosanitary Measures). Part 2 reviews five more agreements and the growing number of bilateral and regional trade agreements, and concludes with a commentary on different strategies proposed to ensure that health is not compromised by trade liberalisation treaties.

See end of article for authors' affiliations ....................

Correspondence to: Professor R Labonte, Globalization and Health Equity, Institute of Population Health, University of Ottawa, 1 Stewart Street, OHtawa Ontario, Canada, K1M 1C7; rlabonte@uottawa.ca

Accepted for publication 26 September 2005

\section{PUBLIC HEALTH IMPLICATIONS OF AGREEMENTS ON INVESTMENTS, GOVERNMENT PROCUREMENT, AND REGULATORY TRADE BARRIERS}

Governments have long used regulations over foreign investment, and their own domestic purchases or issuing of contracts, to fulfil equity oriented policy objectives related to regional development or marginalised groups. These policy flexibilities are increasingly subject to trade treaty restrictions.

\section{Agreement on Trade-Related Investment Measures (TRIMs)}

The TRIMs agreement prevents countries from attaching certain performance requirements (such as minimum levels of local content) to approvals of foreign investment. Such requirements have at times been abused by corrupt politicians and officials leading to "crony capitalism", in which domestic suppliers owned by family members or friends reap most of the performance requirement benefits. Under fairer governance, however, performance requirements have also proved useful in ensuring health promoting employment and income adequacy for marginalised groups or regions. Their removal benefits investors from high income countries much more than it does people living within low and middle income nations. ${ }^{1}$ The TRIMs agreement is limited in scope, restricting only government measures that previously required minimum purchases of local goods by the foreign invested company. Countries are also allowed to impose temporary import restrictions on materials the foreign investor may want to bring into the country for manufacturing purchases, if it is necessary to maintain balance of payments ${ }^{*}$, and there are no restrictions on requirements for technology transfer. ${ }^{3}$ More intrusive are bilateral investment treaties, or BITs, which number over $2200^{4}$ and began their explosive rise after the collapse of talks to create a multilateral agreement on investment (MAI) in the late 1990s.

\section{Agreement on Government Procurement (AGP)}

The AGP requires governments to take into account only "commercial considerations" when making purchasing decisions. It specifically bans preferences based on environment, human, or labour rights and requires that bids for government contracts be open to suppliers from all member nations. Currently a plurilateral (optional) agreement, which few developing countries have signed, the 2001 Doha Ministerial Declaration commits members to negotiate a future multilateral agreement on transparency in government procurement. This might aid in preventing large scale cronyism or misuse of public monies by corrupt officials, with negative health impacts because of the loss of funds for public health and social spending. While the Ministerial Declaration states that negotiations "will not restrict the scope for countries to give preferences to domestic supplies and suppliers", its proponents (primarily the Quadrilateral Group of Canada, the US, Japan and the European Commission) $\dagger$ view it as a first step in creating a broader multilateral agreement that eventually would prevent national governments from giving preference to domestic suppliers in purchases or contracts. This would remove important policy flexibilities through which governments have combated regional unemployment or social marginalisation of particular groups, strategies with important public health benefits. Similar concerns exist with the General Agreement on Trade in Services (GATS). Services committed under GATS that are contracted by governments are exempt from the most restrictive trade rules (most favoured nation, national treatment, and market access; see glossary part

*Balance of payments refers to the difference between the amount of foreign currency coming into a country (including from sales of exports) and the amount leaving (including payments for imports). A large deficit can create serious economic instabilities.

${ }^{\dagger}$ As with any multilateral political process, groups have formed at the WTO embodying different economic, development, and regional interests. The most powerful of these is the Quad (Quadrilateral Group). 
1). But it is not clear when a contracted government service becomes a long term concession that may no longer be exempted, for example, water provision in developing countries that is increasingly being managed through privatisation or mixed public-private partnership schemes. ${ }^{5}$

\section{Agreement on Technical Barriers to Trade (TBT)}

The TBT applies to technical regulations on goods undertaken for reasons of security, health, or environmental protection. It requires that such regulations not create "unnecessary obstacles to international trade" and that any alternative measure that is "less-trade restrictive" must be implemented. ${ }^{2}$ The public health problem arises in the ambiguity of these terms, and that trade policy and not public health experts interpret them in dispute panels. Many governments now routinely scrutinise proposed health and environmental regulations against the TBT agreement and similar WTO trade treaty obligations, resulting in a loss of public health policy flexibility. At the same time, the TBT agreement precludes governments from imposing import restrictions on like products (goods that are identical or similar to each other) whose process and production methods involve environmental pollution or hazardous workplace conditions that exceed standards in their own country. On the one hand, developing countries fear that, if such restrictions were permitted, it would discriminate against them as they lack pollution control or workplace safety technologies. On the other, this provision has made it easier for transnational corporations to locate manufacturing facilities in countries with weaker environmental and occupational standards, reducing their production costs.

\section{PUBLIC HEALTH IMPLICATIONS OF AGREEMENTS COVERING PROTECTION OF INTELLECTUAL PROPERTY RIGHTS AND TRADE IN SERVICES}

The Agreement on Trade-Related Intellectual Property Rights (TRIPS) and GATS have been the subject of intense debate in the public health community for their impacts on access to essential medicines and health care, respectively. The UN Special Rapporteur on the right to health, Paul Hunt, cites both agreements as being in potential conflict with this right. ${ }^{6}$

\section{Agreement on Trade-Related Intellectual Property Rights (TRIPS)}

The TRIPS agreement came into force with the 1995 establishment of the WTO. It commits all current and future WTO members to providing a degree of protection for intellectual property (for example, patents, trademarks, and copyrights) comparable to that available in the developed world. TRIPS specifies a minimum period of patent protection of 20 years from the date of application, although with approval processes the actual protected period may be closer to 12 years. TRIPS also provides for a transitional period before developing countries have to comply with all provisions related to patent protection. For some least developed countries, that transition period will be in effect until 2016. For most others it is now expired.

TRIPS provisions on patent protection quickly became controversial because a number of developing countries provided limited or no patent protection for pharmaceutical products and regarded the production of generic copies of patented medicines as an essential element of their public provision of health care. Affordable domestically produced generics are widely regarded as a key ingredient in Brazil's relative success in controlling AIDS. ${ }^{7}$ The counter argument is that extended patent protection is essential to reward the high investment costs entailed in discovering new drugs. This may be true, although cost estimates are often inflated by pharmaceutical companies, ${ }^{8}$ much of the research involves public subsidies, and other means to reward such costs without extended patent periods have been argued, for example, advance purchase agreements, special competitions, deeper public funding.

Article XXXI of TRIPS provides for compulsory licensing of patented inventions, but only in "a national emergency or other circumstances of extreme urgency" and under terms that would protect patent holders' financial interests, making compulsory licensing unaffordable even when permitted. Campaigns by developing country governments and civil society organisations such as Médecins sans Frontières forced the issue on to the agenda of the Doha ministerial conference and resulted in the Declaration on TRIPS and Public Health. ${ }^{9}$ The Doha Declaration affirmed "that the [TRIPS] Agreement can and should be interpreted and implemented in a manner supportive of WTO Members' right to protect public health and, in particular, to promote access to medicines for all". It further recognised "the right to grant compulsory licences and the freedom to determine the grounds upon which such licences are granted," stating that "each [WTO] Member has the right to determine what constitutes a national emergency or other circumstances of extreme urgency, it being understood that public health crises, including those relating to HIV/AIDS, tuberculosis, malaria and other epidemics, can represent a national emergency or other circumstances of extreme urgency". It was left to the WTO's General Council to determine how the Declaration would modify countries' TRIPS obligations. This process took almost two years largely because of resistance from the US pharmaceutical industry, which pressed the US government to argue for the narrowest possible Interpretation of the Declaration. In the end, the General Council decisions did not restrict the application of the Doha Declaration to specific diseases nor restrict its application to specific kinds of emergencies, leaving definitions up to the relevant national government. It also provides some scope for parallel imports-that is, imports of medicines produced under compulsory licences for countries whose own pharmaceutical manufacturing capacity is insufficient or non-existent. Four problems none the less persist:

(1) The Council decisions do not change the text of the TRIPS treaty but rather are meant to guide its interpretation. They are subject to review and the Decision on parallel imports can be terminated.

(2) There is no guidance on compensation to a patent holder for obtaining a compulsory license, which could result in unaffordable costs.

(3) The rules for compulsory licensing and parallel importing are so complex that, in the words of a leader with the India Pharmaceutical Association, "no generic manufacturer would be able or willing to comply with its provisions". ${ }^{10}$ This is one reason why Canada, a year after changing its drug legislation to allow for parallel exporting, has yet to produce a single generic equivalent for this purpose.

(4) The transition period for India, for years a major source of inexpensive antiretrovirals, ended in 2005, which means it can only produce generic drugs for export if it complies with the Interpretation's complex protocols.

TRIPS is also controversial for its potential to permit biopiracy - the patenting by multinational corporations of life forms originating in poorer nations, including medicinal plants and seeds previously in the public domain. This can affect food security as well as access to traditional remedies. TRIPS allows members to exclude from patentability "plants, animals and essentially biological processes". ${ }^{2}$ But patentability must be extended to microorganisms and 
non-biological or microbiological processes, and plant varieties must be protected by patents or a similar sui generis (historical) system of knowledge protection. Some developing countries believe that TRIPS should be amended to better protect indigenous knowledge; this could promote health by increasing wealth for poorer countries, while also protecting biodiversity by rendering it economically profitable to do so. Others urge that all life forms, including microorganisms and microbiological processes, should be banned from patent protection on the basis that such processes are a discovery, not an invention. This latter is the position consistently argued by the African group. $\neq$ Despite their public health implications, neither of these developing country reform measures was addressed in the Doha Declaration on TRIPS, which focused only on drug patent concerns.§

A troubling development has been the rise in TRIPS-plus agreements. These are regional or bilateral trade treaties whose provisions on intellectual property rights afford fewer policy flexibilities than exist under TRIPS. TRIPS-plus agreements typically add new areas of intellectual property rights, limit the granting of compulsory licences, extend patent protections to transgenic life forms, and create dispute settlement rules biased towards the patent holders. ${ }^{11}$ The public health concern is that such agreements could weaken the small gains made by developing countries at the Doha Ministerial. The USA is reportedly focusing on TRIPS-plus agreements with the expectation that this will eventually force their stronger intellectual property rights into the TRIPS agreement itself. ${ }^{13}$

\section{The GATS agreement}

Services have become increasingly important to the economies of high income countries. GATS came into force with the establishment of the WTO, and is designed to reduce barriers to international trade in services. Liberalised trade in services skews benefits to developed countries with advanced and highly competitive service industries and can undermine domestic service industries in poorer countries. ${ }^{14}$ The GATS is a broad agreement that covers all types of government action that affects trade in services, regardless of how those services are supplied. Certain GATS rules are top-down and apply generally, to all government measures affecting trade in all service sectors. The most important of these is the most favoured nation rule (see glossary part 1).

The most forceful GATS provisions are bottom-up and apply only to those sectors and measures that governments specifically agree to cover. These rules include national treatment and market access (see glossary part 1). In making commitments to these rules governments can specify how they apply to particular services and government measures. Commitments can be unbound (applying only to current government measures) or bound (covering current and any

‡The Africa group comprises all African nations, and has taken the lead on TRIPS agreement amendments.

${ }^{\S}$ Indeed, the focus on drug patents could be a public health distraction. Attaran points out that poverty in developing countries is a bigger reason for lack of access to essential medicines than drug patents protected under TRIPS. ${ }^{12}$ Most essential drugs on the WHO's Model List of Essential Medicines are not patent protected in developing countries, and drug companies often do not pursue such protection in low income countries because of their small market size and lack of ability to pay. Improvements in global health, including curbing of the HIV/AIDS and other infectious disease pandemics, are more likely to arise through reforms in other WTO agreements, such as those covering agricultural subsidies or special and differential treatment, than through reforms in drug patent protection, at least until poorer countries become wealthy enough to matter to the bottom-lines of multinational drug companies.
Table 1 Commitments to liberalise health services ${ }^{24}$

\begin{tabular}{lll}
\hline Service category & $\begin{array}{l}\text { Total WTO } \\
\text { members }\end{array}$ & $\begin{array}{l}\text { WTO developing } \\
\text { country members }\end{array}$ \\
\hline Medical and dental services & 54 & 36 \\
Hospital services & 44 & 29 \\
Nursing and midwifery services & 29 & 12 \\
"Other" health services & 17 & 15 \\
\hline
\end{tabular}

future government measures). They can include limitations on the range of services and measures covered, or they can be without limitations. Commitments can be limited to certain ways of providing services, or they can cover all possible ways of providing the service. This formal flexibility is diminished, however, by intense negotiating pressure to extend the reach of GATS rules with full, bound commitments and minimal limitations.

Several GATS sectors have profound public health implications, notably health, education, and water and sanitation services. ${ }^{515-17}$ These service sectors are among those considered basic to the right to health. ${ }^{18}$ GATS proponents claim that whether liberalisation in such services produces a net public health gain or loss depends on the domestic regulatory structures put in place to manage its impacts. ${ }^{19}$ This may be true. But, referring to health services alone, the 2000 World Health Report cautioned that "few countries (with either high or low income) have developed adequate strategies to regulate the private financing and provision of health services", noting that "the harm caused by market abuses is difficult to remedy after the fact". ${ }^{20}$

The GATS market access rules also apply to measures known as quantitative restrictions in other WTO agreements. Quantitative restrictions, or QRs are explicit numerical limits, or quotas, on trade measured by quantity or monetary value. GATS prohibits governments from enacting regulations and other measures that have the effect of limiting access to their services markets, the number of service suppliers and their employees, quotas on the value of services provided, or the type of legal entity permitted to provide a service. These rules apply even if the measure is non-discriminatory-that is, even if domestic and foreign provided goods or services are equally affected. This broad definition of QRs may diminish the capacity of governments to contain health costs (by restricting the number of providers) or to ensure equitable regional distribution of health providers.

The principal concern with GATS lies in whether liberalisation commitments will lead to increased private financing and provision of what are presently publicly financed and provided health and other key health determining services. ${ }^{* *}$ The GATS agreement, while not the key driver of services privatisation, locks in existing levels and secures and entrenches pro-competitive policies in areas where countries

"The GATS defines four possible ways of providing services, or modes of supply. Each of these can apply to public health services: (1) crossborder delivery of services (such as shipment of laboratory samples or provision of telehealth services); (2) consumption of services abroad (called "health or medical tourism"); (3) commercial presence (foreign investors provide private hospitals, clinics, treatment centres, insurance or facilities management); (4) presence of natural persons (the temporary movement of health professionals from one country to another).

** Or, in the case of many developing countries, services that were publicly financed and provided before structural adjustments imposed by the World Bank and IMF led to their full or partial privatisation. 
have made commitments. ${ }^{17}$ Increased private financing and provision inevitably follows. †† A country can reverse its GATS commitments only by negotiating trade compensation for any affected countries. Moreover, a top down GATS requirement commits all WTO members to progressive liberalisation, where successive negotiating rounds aim to achieve a "progressively higher level of liberalisation" in all service sectors (Article XIX). This reinforces a negotiating dynamic that seeks to continually extend the reach of GATS rules and makes it difficult to maintain limitations or exceptions that shield health care or other health promoting services. The UK Commission for Africa 2005, a high level group created by the British government to advise on industrial world policies towards persisting African health and development crises, cautioned that GATS-like all WTO trade treaties, a commercial agreement aimed at increasing private sector trade-is not an appropriate vehicle through which developing countries should undertake liberalisation of any of their service sectors; "forcing countries to liberalise through trade agreements is the wrong approach to achieving growth and poverty reduction in Africa, and elsewhere" ${ }^{\prime 21}$

Services negotiations intensified in late 2005 as the EU and other developed countries sought increased market access in the developing world. At the 2005 Hong Kong ministerial meeting, WTO members agreed to ambitious goals for agreement by the end of 2006, including significantly extending market access commitments, developing new rules on domestic regulation, and reducing entry restrictions on temporary workers. A plurilateral negotiating process was introduced to induce more extensive market access commitments than have been secured through the bilateral requestoffer process. Developing countries made a disproportionate share of GATS commitments in 1995 and often included fewer limitations than those specified by industrialised countries $^{22}$ (see table 1 ).

Evocative of the complexity of the agreement, the Canadian government, which steadfastly refuses to commit any of its health services to liberalised trade, unintentionally committed to liberalise trade in health insurance in 1995. Negotiators were apparently unaware that this was covered in the section on financial, rather than health, services. As a result, if Canada extends public insurance into areas where there are presently foreign private providers operating (for example, for dental care or home care) it could face a trade challenge. $^{23}$

\section{THREE PERSISTING ISSUES IN THE PUBLIC HEALTH/ TRADE AGREEMENT NEXUS \\ Erosion of the precautionary principle}

The precautionary principle has become an important public health concept and tool where there remains lack of scientific certainty over environmental risks of widespread and serious potential health consequences. The essence of this principle is "when in doubt, err on the side of public (or environmental) health". There are differing opinions on the extent to which this principle has been eroded by trade treaties, notably the SPS agreement and its requirement for a scientific risk assessment of health and environmental regulations, even when such regulations are not trade discriminatory. ${ }^{25-27}$ While WTO dispute panels acknowledge the right of governments to enact regulations that may be more stringent than international standards, the burden of proof for the necessity of such

\footnotetext{
${ }^{+t}$ We set aside an examination of whether increased private financing or provision in health care and other important health determining services is a good or bad thing for the public's health. What such privatisation does do, however, is limit or remove the ability to cross subsidise the costs of such services from healthy to sick and from rich to poor, rendering whatever mixed system results less fair.
}

regulations, and eventual costs of a mistake, rests entirely with the importing country. This allocation of risk contradicts many multilateral environmental agreements, notably the Cartagena Protocol on Biosafety that, in keeping with the precautionary principle, puts the burden of proof on the exporter. Civil society organisations have argued that disputes under the SPS or TBT agreements should similarly reverse the onus so that challenging countries need to prove that a particular regulation was not necessary to achieve its purpose, or could have been substituted with a measure that is less burdensome on trade.

\section{Regulatory chill}

Regulatory chill is a term coined to describe the impact of the potential costs of trade disputes on governments' willingness to introduce new health regulations. An oft cited case involved Guatemala, which backed away from a US complaint on behalf of Gerber Foods that its legislation entrenching the WHO's International Code on Marketing of Breast-milk Substitutes—which prohibits marketing showing pictures of babies-expropriated Gerber's intellectual property rights in the form of its "pudgy baby" trademark. ${ }^{28}$ The dispute was never heard because the potential costs of defending it were beyond Guatemala's financial reach or priorities. Guatemala amended its legislation to permit imported, but not domestic, infant formula to show healthy babies on its products. The Canadian government similarly let its legislation for plain packaging of tobacco products die after representatives of Phillip Morris International and R J Reynolds Tobacco International argued that it constituted an expropriation of assets (their trademarks), violating NAFTA (North American Free Trade Agreement) investment, and intellectual property obligations. Again, the dispute was never heard but the costs of fighting the dispute, and possibly losing, were sufficient to "chill" the regulatory option.

\section{Implementation costs}

Meeting trade treaty obligations entails direct domestic costs to countries in the form of legislative changes, new regulations and their administration, changes in production to meet international standards, and so on. These costs are disproportionately borne by least developed countries often at the expense of health and social spending. ${ }^{29}$ WTO member nations consistently promise technical assistance to least developed countries for implementation, but financial levels for this support have been meagre. ${ }^{22-30}$ For "most of the developing and transition economies-some 100 countriesmoney spent to implement the WTO rules...would be money unproductively invested". ${ }^{29}$

\section{REGIONAL AND BILATERAL TRADE AGREEMENTS}

WTO trade treaties are not the only ones with public health implications. NAFTA, CAFTA (Central American Free Trade Agreement), and MERCOSUR (a free trade agreement involving Argentina, Brazil, Uruguay, and Paraguay) are among several regional treaties in the Americas. Efforts continue to create an overarching Free Trade Area of the Americas (FTAA). SADC (Southern African Development Community, which is presently negotiating a customs union), ASEAN Free Trade Area (an agreement between 10 South East Asian nations), and the EU (European Union) are examples of other regional agreements. The EU is unique because it is both a customs union, in which all goods cross borders tariff free, and a political union with elected representatives, upwards harmonisation of social programmes and transfer payments/loans between richer and poorer regions (although these mechanisms have been undermined by a recent "corporate Europe" orientation). Unlike other commercial trade agreements, the EU is an 
established supranational political system with social, as well as economic, obligations.

Emergence of the WTO in 1995 has not slowed the development of regional or bilateral (two nation) trade agreements. These agreements are invariably more liberalised than those under the WTO, as the GATT 1994 (Article XXIV), which permits the creation of such exclusive agreements between WTO Member nations, requires that they cannot, on average, be more trade restrictive than what existed before the new agreement.

A controversial feature of many of these agreements, particularly those involving the USA (such as NAFTA, CAFTA, and the proposed FTAA) is investor-state provisions that allow private corporations to start disputes against governments. NAFTA's Chapter 11 is the model for such provisions, and resulted in 39 such challenges in its first 10 years of effect, ${ }^{5}$ most of which have yet to be settled. Examples with public health implications include Canada's retreat from plain packaging for cigarettes (described earlier), withdrawal of a ban on a potentially neurotoxic gasoline additive, a fine against a Mexican municipality for stopping creation of a toxic dump site that could pollute its source of drinking water, and an attempt by an American water company to sue a Canadian province for over $\$ 10$ billion in lost potential earnings from its ban on bulk water exports.

Similar investor-state provisions are found in most of the proliferating bilateral investment agreements (BITs). BITs are often promoted as a means of stimulating foreign direct investment (FDI) that is assumed, in the case of developing countries, to be beneficial to economic growth and poverty reduction, hence health improvementłł. In reality, most BITs are intended only to protect existing and subsequent FDI, ${ }^{4}$ and are more restrictive of performance requirements governments might impose on FDI than is the WTO's TRIMs agreement (see above). Many of the scores of BIT cases now in arbitration relate to Latin American water concessions, where private investors are seeking to overturn government regulations on tariffs, taxes, and water quality, with obvious negative health implications. Some foreign mining companies are threatening to use BITs to seek high levels of compensation from the South African government that, to rectify the historical exclusion of the black majority from the country's economy, is changing its domestic legislation on ownership of mineral resources ${ }^{4}$ BITs generally lack any reference to development goals and dispute tribunals have erred on the side of protecting foreign investors. This effectively minimises any risks they face because of changing sociopolitical, economic, or environmental conditions. Governments intervening to mitigate the health or social costs of changed conditions, or to respond to citizens' needs for better living conditions, could face costly challenges and fines if their actions diminish the profitability of foreign investments.

\section{OPTIONS FOR STRONGER PUBLIC HEALTH CONSIDERATIONS IN WTO AGREEMENTS}

Part 1 of this glossary cautioned that the links between liberalisation, growth, and poverty reduction are tenuous, sometimes contradictory, and not universal. There is similarly no easily generalised relation between trade liberalisation, poverty, and health. Moreover, trade rules have been interpreted and applied in unforeseen ways, and with unpredictable health consequences. Developing and least developed countries also continue to face enormous challenges in trade negotiations, as they lack the human

¥¥ We emphasise that this an assumption only; evidence suggests that FDI follows economic growth at least as much as leads it. Nor does economic growth invariably reduce poverty. ${ }^{31}$ resources to participate as fully and knowingly in the many ongoing WTO negotiations-to say nothing of the multiplying bilateral and regional trade treaty negotiations.

Of greatest concern is the loss of governments' future policy flexibility, be it in provision of public services, harnessing foreign investment for equity oriented policy objectives, or protecting increasingly scarce environmental resources essential to public health. Over the years, several ideas have been advanced to ensure that trade agreements fulfil the development goals contained in the WTO's unenforceable preamble.

\section{Social clauses}

At the first WTO Ministerial Conference in 1996, Oxfam led a number of organised labour and public interest groups in advocating that the WTO strike a Working Group to look at incorporating the International Labour Code within its agreements. Oxfam emphasised the need to move slowly in such incorporation for developing and least developed countries-that is, it recognised their need for special and differential treatment (SDT; see glossary part 1). Despite nominal support from the EU and the USA the initiative failed, although it did spark momentum for the idea of social clauses-amendments to WTO agreements permitting use of trade sanctions against countries that failed to live up to core human and labour rights or multilateral environmental agreements. But the idea has met with stiff resistance from the WTO Secretariat and trade negotiators, who argue that it would complicate an already complex set of negotiations. It is also opposed by many developing countries, which fear that such clauses could become a backdoor protectionism for wealthy countries with greater capacity to comply with such clauses. $^{32}$ As recently as 2004, the AFL-CIO, the largest US labour federation, called on its government to impose economic trade sanctions against China, which it claimed brutally repressed workers' rights to gain a competitive advantage. The US administration rejected the argument, claiming that increased trade with China would be a more effective measure. ${ }^{33}$ Both of these claims may have some truth, both mask self interest, and whether workers' rights would be better improved by sanctions or retaining the status quo remains moot.

\section{Conventions outside of commercial trade agreements} The existence of the Framework Convention on Tobacco Control has raised the possibility of creating other health specific conventions outside of the ambit of WTO or other trade treaties. Concern over the long term implications of the GATS agreement on health or health related services, for example, could be mitigated by a convention on international exchanges in these service sectors. Such a convention would privilege the progressive realisation of the right to health, rather than progressive liberalisation in services trade, as both the goal and the standard against which disputes might be resolved. The Canadian government has been promoting creation of such a convention in the area of cultural diversity, with the expectation that a country's domestic policies protecting cultural goods or services would be exempt from trade challenges§§. By promoting conventions such as these national governments can strengthen the international legal and institutional basis for collaboration to promote health, and provide a counterbalance to international trade treaties.

\section{Exemptions for purposes of attaining development goals}

There is increased acceptance that developing countries fared less well in the Uruguay Round of negotiations that created

${ }^{\S}$ How eventual conflicts between the Convention's terms and WTO treaty obligations will be resolved remains uncertain. 
the WTO than did the Quad and other wealthier nations. At the same time, the Millennium Development Goals (MDGs), a UN adopted set of development targets most of which are directly or indirectly related to health, have gained considerable multilateral policy attention. This has led some analysts to suggest that trade agreements be subordinate to these goals; developing countries would be exempt from trade treaty obligations if they could show its necessity to achieving the MDGs. Specifically, a trade challenge against a developing country would be diverted from the WTO's dispute resolution process to a panel of development experts who would review the challenge in light of the MDGs, or any subsequent set of multilateral development targets. This exemption process would satisfy the criticism of two UN Special Rapporteurs on Globalization and Human Rights who concluded that "it is necessary to move away from approaches that are at hoc and contingent" in dealing with conflicts between trade, human rights, and development. ${ }^{34}$

\section{CONCLUSION}

Many civil society organisations urge the elimination of the WTO, with its intrusive rules that favour commercial trade over domestic health and social policy. Others contend that it should "shrink or sink," its scope scaled back to trade in goods and tariff barriers only, leaving services, investment, and non-tariff barriers (domestic policies and regulations) outside of liberalisation agreements. Still others worry that, as the economies of larger developing countries grow and the developing country majority of WTO members organise more effectively to negotiate around their interests, the organisation may be abandoned by wealthier countries whose own interests can be served better through bilateral or regional trade negotiations. Without some multilateral trade rules, it is feared, economic might will invariably eclipse development right.

Proponents of global trade just as invariably point to its benefits-greater wealth, less poverty, better health. The environmental externalities (resource depletion, increased fossil fuelled production and transport) are acknowledged in passim but resolution for which is left to vaguely worded provisions in only some, not all, trade agreements for "technology transfer." The basic political question of whether free market practices are compatible with human development and public health objectives is rendered into a technical disagreements over the interpretation of this or that exemption or exception, interpretations that inevitably will be left to dispute panels dominated by experts in trade policy and law, not in development or public health.

History offers reason to be cautious about the beneficent claims of global trade. Earlier eras of such trade were linked with the spread of disease leading to public health imposed quarantines on merchant goods. Any slowdown in the movement of goods, however, meant a decline in commercial profit, straining relations between health authorities and the merchant class. Lacking definitive proof of the germ theory of disease, public health leaders eventually retreated to the environmental theory of miasma-one that similarly lacked proof but that posed no threat to commercial interests. ${ }^{35}$

\section{WHAT ROLE DOES THIS LEAVE FOR PUBLIC HEALTH PROFESSIONALS?}

Firstly, exercising the precautionary principle, public health can become more engaged with government trade negotiators in their continuous development of both WTO and regional or bilateral trade agreements. This could be aided by development of a "right to health impact assessment methodology" for trade agreements, as called for by the UN Special Rapporteur on the right to health in his 2004 mission to the WTO. ${ }^{36}$
Secondly, public health can become more engaged with trade policy experts advising governments on the protection and use of existing policy flexibilities within trade agreements, particularly for purposes of sustaining or improving health. Public health's traditional concerns with infection control, primary health care, food safety, environmental quality, and prevention of chronic disease afford it entry points for advancing particular trade policy options.

Thirdly, public health can support the work of civil society organisations and emergent global health movements, such as the Peoples' Health Movement, which have often undertaken the most trenchant critiques or studies of the health limitations of unfettered global liberalisation.

The challenge is not to eliminate global trade rules, but to achieve a more appropriate balance in which the goals of human development and public health take precedence.

\section{ACKNOWLEDGEMENTS}

For helpful comments and contributions to an earlier draft, Ted Schrecker, senior policy researcher, Globalization and Health Equity, Institute of Population Health, University of Ottawa; and Scott Sinclair, trade policy analyst, Canadian Centre for Policy Alternatives for Policy Alternatives; and to three reviewers.

\section{ADDENDUM}

An authors' error occurred in the first part of this glossary (2006;60:655-61). Reference 8 should read World Trade Organisation. What is the WTO? http://www.wto.org/english/ thewto_e/whatis_e/tif_e/factl_e.htm\#bird (accessed 5 Jul 2006).

\section{Authors' affiliations}

R Labonte, Globalization and Health Equity, Institute of Population Health, University of Ottawa, Ontario, Canada

M Sanger, Canadian Centre for Policy Alternatives, Ottawa, Ontario, Canada

\section{REFERENCES}

1 Greenfield G. The WTO agreement on Trade-Related Investment Measures (TRIMS). Canadian Center for Policy Alternatives Briefing Paper Series: Trade and Investment $2001 ; 2: 1-8$.

2 Das BL. The world trade organisation: a guide to the framework for international trade. New York: Zed Books, 2000.

3 Vivas-Euguie D. Regional and bilateral agreements and a TRIPS-plus World: the Free Trade Area of the Americas. Geneva: Quaker United Nations Office/ International Centre for Trade and Sustainable Development, 2003.

4 Peterson LE. Bilateral investment treaties and development policy-making. Winnipeg, Canada: International Institute for Sustainable Development, 2004.

5 Sinclair S. The GATS, South African local governments and water services. Canadian Center for Policy Alternatives Briefing Paper Series: Trade and Investment 2005:6:1-13.

6 Hunt P. Economic, social and cultural rights: the right of everyone to the enjoyment of the highest attainable standard of physical and mental health 2003. http://www.unhchr.ch/Huridocda/Huridoca.nsf/(Symbol)/ E.CN.4.RES.2003.28.En?Opendocument (accessed 19 May 2004).

7 Galvao J. Access to antiretroviral drugs in Brazil. Lancet 2002;360:1862-5.

8 People's Health Movement, Global Equity Gauge Alliance, Medact, eds. Global health watch 2005-2006. London: Zed Books, 2005.

9 World Trade Organisation. Declaration on the TRIPs agreement and public health. WT/MIN(01)/DEC/2. 2001. http://www.wto.org/english/ thewto_e/minist_e/min01_e/minded_trips_e.htm (accessed 18 Sep 2002).

10 Jawara F, Kwa E, Sharma S. Behind the scenes at the WTO: the real world of international trade negotiations/lessons of Cancun. 2nd ed. London, Zed Books, 2004:xxxiii.

11 Roffe P. Bilateral agreements and a TRIPS-plus World: the Chile-USA Free Trade Agreement. Geneva: Quaker United Nations Office/International Centre for Trade and Sustainable Development, 2003.

12 Attaran A. How do patents and economic policies affect access to essential medicines in developing countries? Health Aff 2004;23:155-66.

13 Vivas-Euguie D. Regional and bilateral agreements and a TRIPS-plus World: the Free Trade Area of the Americas. Geneva: Quaker United Nations Office/ International Centre for Trade and Sustainable Development, 2003.

14 Jawara F, Kwa A. Behind the scenes at the WTO: the real world of international trade negotiations. London: Zed Books, 2003.

15 Sanger M. Reckless abandon: Canada, the GATS and the future of health care. Ottawa: Canadian Centre for Policy Alternatives, 2001.

16 Equinet. The GATS threat to public health: A joint submission to the world health assembly 2003. http://www.wdm.org.uk/cambriefs/gatshealth.pdf (accessed 17 May 2004). 
17 Pollock A, Price D. The public health implications of world trade negotiations on the general agreement on trade in services and public services. Lancet 2003;362:1072-5.

18 Hunt P. Economic, social and cultural rights: the right of everyone to the enjoyment of the highest attainable standard of physical and mental health 2003. http://www.unhchr.ch/Huridocda/Huridoca.nsf/(Symbol)/ E.CN.4.RES.2003.28.En?Opendocument (accessed 19 May 2004)

19 Adlung R, Carzaniga A. Health services under the General Agreement on Trade in Services. In: Vieira C, Drager N, eds. Trade in health services: global, regional and country perspectives. Washington, DC: Pan American Health Organization, 2002:13-33.

20 World Health Organisation. World health report 2000: health systems improving performance. Geneva: WHO, 2000.

21 Commission for Africa. Our common interest: report of the Commission for Africa. http://www.commissionforafrica.org/english/report/ introduction.html (accessed 10 Mar 2005)

22 Labonte R, Schrecker T, Sanders D, et al. Fatal indifference: the G8, Africa and global health. Cape Town: University of Cape Town Press, 2004.

23 Campbell B, Blouin C, Foster J, et al. Putting health first: Canadian health care, trade treaties and foreign policy 2002. http://www. policyalternatives.ca/ (accessed 10 Mar 2005).

24 Adlung R, Carzaniga A. Health services under the general agreement on trade services. Bull World Health Organ 2001;79:352-64.

25 Bloche MG. WTO deference to national health policy: towards an interpretive principle. J Int Economic Law 2002;5:825-48.

26 Covelli N, Hohots V. The health regulation of biotech foods under the WTO agreements. J Int Economic Law 2003;6:773-95.

27 Drache D, Froese M, Fuller $M$, et al. One world one system? The diversity deficits in standard-setting, development and sovereignty at the WTO. Toronto: Robarts Center for Canadian Studies, York University 2002, http:// www.yorku.ca/robarts/projects/wto/pdf/oneworldonesystem_new.pdf (accessed 1 Feb 2005).
28 Wallach L, Sforza M. Whose trade organisation? Washington: Public Citizen, 1999.

29 Finger JM, Schuler P. Implementation of Uruguay round commitments: the development challenge. In: Hoekman B, Martin W, eds. Developing countries and the WTO: a pro-active agenda. Oxford: Blackwell Publishers, 2001:115-30.

30 Blackhurst R, Lyakurwa B, Oyejide A. Options for improving Africa's participation in the WTO. In: Hoekman B, Martin W, eds. Developing countries and the WTO: a pro-active agenda. Oxford: Blackwell Publishers, 2001:95-114.

31 Labonte R, Schrecker T, Sen Gupta A. Health for some: death, disease and disparity in a globalizing world. Toronto: Centre for Social Justice, 2005.

32 Labonte R. Brief to the World Trade Organisation: world trade and population health. International Journal of Health Promotion and Education 2000; Vl:24-32.

33 BRIDGES Weekly Trade News Digest;8:5 May 2004. http://www.ictsd.org/ weekly/.

34 Oloka-Onyango J, Udugama D. Economic, social and cultural rights: globalization and its impact on the full enioyment of human rights, final report. Geneva: United Nations Economic and Social Council, 2003, Document E/ CN.4/Sub.2/2003/14.http://www.unhchr.ch/ (accessed 1 Feb 2005).

35 Ringen K. Edwin Chadwick, the market ideology and sanitary reform. On the nature of the 19th century public health movement. Int J Health Serv 1979:9:107-20.

36 Hunt $\mathbf{P}$. Economic, social and cultural rights: the right of everyone to the enjoyment of the highest attainable standard of physical and mental health report of the Special Rapporteur - Addendum: Mission to the World Trade Organization. New York and Geneva: United Nations Economic and Social Council, 2004, Document E/CN.4/2004/49/Add.1.http:// www.unhchr.ch/huridocda/huridoca.nsf/0/ 5860D7D863239D82C1256E660056432A/\$File/ G0411390.pdf?OpenElement (accessed 1 Feb 2005).

\section{The Society for Social Medicine 50th Annual Scientific Meeting: 13-15} September 2006, The University of Leeds

JECH 2006;60:suppl I

The abstracts from this meeting are available as an online only supplement and can be read at http://jech.bmijournals.com/supplements.shtml 